\title{
Wild Oats Unique Nutritional Healthy
}

\author{
Ali Khider M. Alazzam \\ Northern Technical University Technical Institute of Mosul
}

\begin{abstract}
Recently although of global population growth require explore alternative food energy in harmonize with human health as Wild Oats, it is herbaceous winter plant follows Poaceae family and spread widely in northern of Iraq to fit environmental conditions in espial Sulaymaniyah province that the rainfall reaches(656.05)mm which allowed it to grow as a first vegetation cover found through field survey; frequency(55),Density plant/m ${ }^{2}$ (26),plant height (50- 170) $\mathrm{cm}$, number of tillers(5), the length of the blade( 25) cm, number of inflorescences $(5-7)$, the number of seeds per plant (350), weight of 1000 grain (22.90) gm. either of nutritional importance comes from the high proportion of protein (16.9\%), carbohydrates(66.3\%), oil(6.9\%) and minerals (Fe, Ca, $K, P)$ and vitamins( $A$, $B 1, B 2, C, D)$.Consider good palatable forage to animals as hay and silage, their medical importance comes by treats the high blood pressure, diabetes and helps to reduce the cholesterol content in the blood.Wild Oats is an important as a sexual tonic which increases the enjoyment and frequency of orgasms.
\end{abstract}

Keywords: Oats, Health, environment, plant, biological diversity

\section{Introduction}

Due to a favorable environmental conditions in northern Iraq, which contributed to the establishment of vegetation are the most important factors rainfall ranging from $(500$ $800) \mathrm{mm}[1]$.Spreading wild oat plants in various countries of the world in Asia, Africa, America and Europe and within all different species follow the same genus [2] Most studies of the importance of plant food appeared the chemical content of higher proteins, carbohydrates and oils which enters in various food industries for being equipped with 389 calories also has a medical importance as a natural product which contributes to the treatment of many diseases[3]To plant forage importance that consider natural pasture where it can be synthesized hay and silage. Wild Oats was significance to improvement of environmental status, for its highly spread and studies indicated that the morphological properties were characterized by a total density vegetative per area unit, the percentage of the plant frequency, coverage area that reduce moisture loss from the soil and contributes to the activation of biodiversity, with positive interaction form within its native $[4,5,6]$. Therefore, requires the attention with conservation its sustainability by preparation the studies and researches in order to contribute its economic development by its comparable among other cereal crops that researcher considered it harmful plant as weed. [7].

\section{Materials and Methods}

The research was conducted in the province of Sulaimaniyah outside of cultivated lands by conducting a field survey in the area of the plant spread snapped a random sampling area of $(50 \times 50) \mathrm{cm}$ within the wooden frame, where made classification and isolate the plants within the frame and studied the following characteristics; plant density, replication, tillers number, leaves number per plant, blade length, inflorescences number, seeds number per plant, grain weight of (1000) gm. The study area was diagnosed according the following equation by climatic factors in addition to morphological characteristics of the plant been assessing food and medical value in addition to pastoral and environmental importance.

\section{Results and Discussion}

Found during the study that plant of Wild oats more proliferation in the province of Sulaymaniyah in out cultivated and planted lands with wheat and barley (Ahmed Sultan)due to suitable environmental factors showed in the table( 1) found that annually rate of temp. (19.6) $\mathrm{C}^{0}$ humidity (45.0\%), evaporation (162.7) $\mathrm{mm}$, rainfall (656.6) $\mathrm{mm}$ [1]. which conducted assess the climate factor from Dorbanton equation that the drought indicator was (33) from this value possible to classify the status of climate of the region by very humid as the table (2). Found the first plant prevalent in Sulaimaniyah, in terms of high density, replication, a plant height reached $(50-170) \mathrm{cm}$, contains a plant (4.5) hollow inter node, number of the tillers (5), leaf length $(25) \mathrm{cm}$, number of inflorescences (5- 7), the floret number (1-4) seed length $(8-12) \mathrm{mm}$. plant tolerant high $\mathrm{pH}$ more than wheat, barley and success planting in heavy soil a good drainage and tolerant for freezing $(-4) \mathrm{C}^{\mathrm{o}}$, but the plant need moisture more than wheat and barley. The wild Oats consider alternative grains because of its importance as food for humans which used as Oats milk, cakes, and morning soups in most European countries. Can making bread after mixed with wheat flour this idea was certify with [8].Oats are among the world's healthiest grains it contain $(16.9 \%)$ protein, $(6.9 \%)$ fat, $(66.3 \%)$ carbohydrates, $(10.6 \%)$ fiber and amino acids such as Allergen, licin and tryptophan, vitamin ( A, B1,B2,C, $\mathrm{D}$,)and minerals ( $\mathrm{Fe}, \mathrm{Ca}, \mathrm{K}, \mathrm{Mg}, \mathrm{Zn}, \mathrm{P}, \mathrm{Na}$ ) table (3), extracted from it furfural material which used in the purification of salt and the removal of pigments. Oil of Oats was unsaturated an important source of vitamins, minerals and trace elements, fatty acids, Carbs, Starch, protein. Wild oats are a rich source of soluble fiber called beta-glucans that reduce blood cholesterol and control blood sugar and improves immune function. Increases orgasm through liberalization of testosterone (sex hormone most associated with sexual lust), which increases compliance in the body with age, it has been noted that both men and women feel a significant increase in the desire for sexual activity after eating Oats. These results are consistent with the reach of $[9$, 10 , and 11]. 


\section{International Journal of Science and Research (IJSR) \\ ISSN (Online): 2319-7064}

Index Copernicus Value (2015): 78.96 | Impact Factor (2015): 6.391

\section{Recommendations}

1) Must be conservation on the sustainability form of the natural plants such as wild oats for its contribution in biological diversity.

2) Never using chemical control methods on rid of herbs because the vegetation cover consider as ecosystem contributes to the improvement of the environment and that was one of the single of vegetation cover.

3) Never overgrazing and the launch of the animals in areas where wild plant spreads like wild oats to sustain its life and achieve generational succession of the plant

4) Observed using mechanical skimmers to strip the territory of its container as well as the removal of these plants by fires.

Table 1: Monthly average of climate data in study region

\begin{tabular}{|c|c|c|c|c|}
\hline Month & $\begin{array}{c}\text { Temp. } \\
c^{0}\end{array}$ & Humidity \% & Evapro. mm & Rainfall mm \\
\hline October & 22.3 & 32.8 & 141.6 & 38.22 \\
\hline November & 14.0 & 57.2 & 72.6 & 63.50 \\
\hline December & 8.4 & 61.2 & 51.4 & 81.80 \\
\hline Jan. & 6.5 & 70.3 & 53.4 & 24.40 \\
\hline Feb. & 7.8 & 65.4 & 54.1 & 125.10 \\
\hline Mar. & 12.8 & 54.9 & 97.1 & 88.10 \\
\hline Apr. & 17.3 & 55.1 & 132.8 & 95.19 \\
\hline May & 24.0 & 41.6 & 226.4 & 37.89 \\
\hline
\end{tabular}

\begin{tabular}{|c|c|c|c|c|}
\hline June & 29.6 & 26.4 & 312.4 & 0.57 \\
\hline July & 31.8 & 25.2 & 225.6 & 0.00 \\
\hline Aug. & 33.2 & 24.9 & 323.9 & 0.02 \\
\hline Sep. & 28.0 & 28.4 & 234.7 & 1.26 \\
\hline Annually rate & 19.6 & 45.0 & 162.7 & 656.05 \\
\hline
\end{tabular}

From the climate factors were classified the study region by using the Durbaton equation of drought indicator as following:

$\mathbf{D} \mathbf{I}=\mathbf{P} / \mathbf{T}+\mathbf{1}$

Where

$\mathrm{P}$ : Total rainfall $/ \mathrm{ml} ; \mathrm{T}$ : The annual average temperature $\mathrm{C}^{0}$.That (D I) calculated 14.75 when comparing this value with the values of table (2) conclude that the prevailing climate being classified as Semi-humid type.

Table 2: Determine the status of the climate and the type of vegetation in according to Dumbarton equation

\begin{tabular}{|c|c|c|}
\hline Drought indicator & $\begin{array}{c}\text { Dominant climate } \\
\text { character }\end{array}$ & Type of Vegetation cover \\
\hline Less than 5 & Dry & Steppe, deserts \\
\hline $5-9.9$ & Semi- dry & Rain fed agriculture \\
\hline $10-19.9$ & Semi- humid & Herbs \\
\hline $20-29.9$ & Humid & Trees \\
\hline More than 30 & Very humid & forests \\
\hline
\end{tabular}

Table 3: Chemical composition of Wild Oats

\begin{tabular}{|c|c|c|c|c|c|}
\hline $\begin{array}{c}\text { Biochemical } \\
\text { composition }\end{array}$ & AMOUNT & Minerals & DV $\%$ & Vitamins & $\%$ DV \\
\hline Compound & $\%$ & $\mathrm{Ca}$ & $5 \%$ & $\mathrm{~B} 3$ & $6 \%$ \\
\hline protein & 16.9 & $\mathrm{Fe}$ & $59 \%$ & $\mathrm{~B} 5$ & $27 \%$ \\
\hline carbs & 66.3 & $\mathrm{Mg}$ & $44 \%$ & $\mathrm{~B} 6$ & $9 \%$ \\
\hline fiber & 10.6 & $\mathrm{P}$ & $75 \%$ & & \\
\hline fat & 6.9 & $\mathrm{Na}$ & $0 \%$ & & \\
\hline & & $\mathrm{Zn}$ & $36 \%$ & & \\
\hline & & $\mathrm{mn}$ & $214 \%$ & & \\
\hline
\end{tabular}

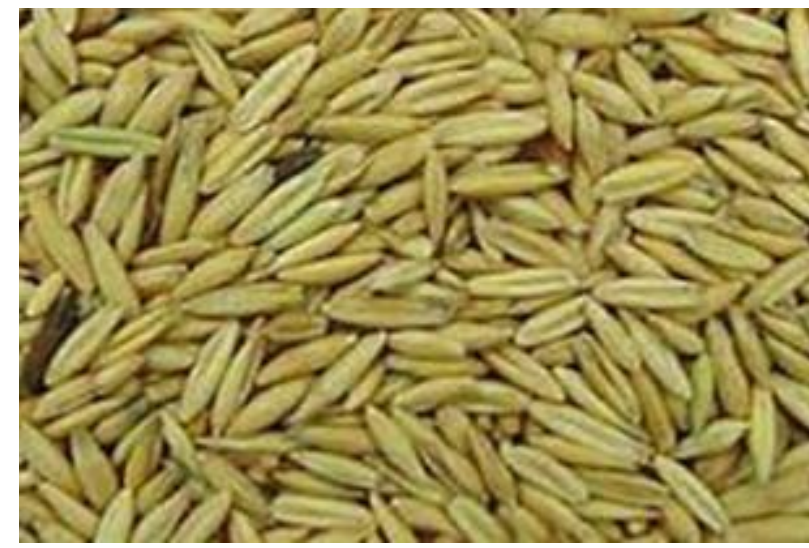

Figure 1: Explain Wild Oats grain

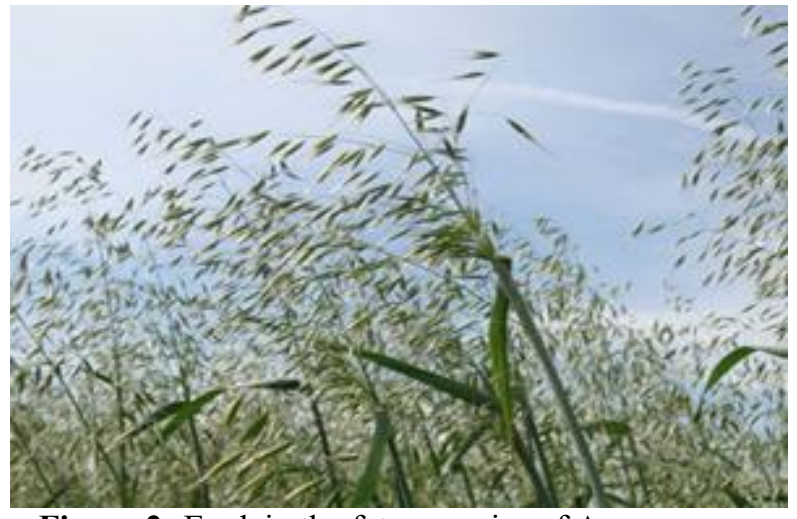

Figure 2: Explain the fatua species of Avena genus

\section{References}

[1] Ali Khider M. Al-Azzam,2016, Evaluation vegetation cover in Sulymaniyah region of IRAQ, Int. J. Adv. Res.vol.0 4 issue,(9), p 2056-2062.

[2] KentL., N.L. Kent (Ed.), 1983,, Oats In: Technology of Cereals. 3rd end. Pergamon Press, Oxford; p.165-174.

\section{Volume 6 Issue 1, January 2017




\section{International Journal of Science and Research (IJSR) \\ ISSN (Online): 2319-7064}

Index Copernicus Value (2015): 78.96 | Impact Factor (2015): 6.391

[3] Lin, F.D., Knabe, D.A., Tanksley, T.D.,2007,Apparent digestibility of amino acids, gross energy and starch in corn, sorghum, wheat, barley, oat groats and wheat middlings for growing pigs. J. Anim. Sci.; 64: p.16551663.

[4] Ibraheem.M.Aliyas,Ali Kh.Alazzam and SalemA.Hassen,2016,ASSESSMENT THE BIODIVERSITY IN THE NATURE RESERVE OF SINJAR MOUNTAIN,journalcra,Vol.8(11),pp,20562062.

[5] Sosulski, F.W., Sosulski, K., 1985, Processing and composition of wild oat groats (Avena fatua L.). J. Food Eng.; 4: p.189-203.

[6] Sosulski, F.W., Sosulski, K., Olson, J.P., 1985,Nutritive value of wild oat groats and flakes. Can. Inst. Food Sci. Technol.; 18: p.220-225.

[7] 1.Campbell, et al, 2007, Nutritive value of irradiated and beta-glucanase treated wild oat groats (Avena fatua L.) for broiler chicks. Anim. Feed Sci. Technol.;16:p.243-252.2

[8] Seema Sangwan et al, 2014, Nutritional and functional properties of Oats, Vol.(1),Issue (1),p.003-14.

[9] Halina Gambuset al,2011, The Application of Residual Oats flour in bread production order to improve its quality and biological value of protein V01. (10), issue(3), p.313- 325. Quarterly Stats on sex declinepart 1 p.29. James Meschino DC, MS, N

[10] Medd, R.W., 1996, Wild oats-what is the problem? Plant Protection Quarterly 11(1), 183-184.

[11] Judith C. Thalheimer, et al, 2013, A Soluble Fiber Primer - Plus the Top Five Foods That Can Lower LDL Cholesterol, Today's Dietitian Vol. 15, No. 12, P. 16. 